\title{
Exploring Relationship among Factors of Virtual Communities, Trust and Buying In Pakistan
}

\author{
Muhammad Nouman Shafique ${ }^{1 *}$, Naveed Ahmad ${ }^{2}$, Iqbal Kiani ${ }^{3}$, \\ Muhammad Ibrar ${ }^{4}$ \\ 1,3,4 Scholar Preston University, Islamabad, Pakistan \\ ${ }^{2}$ Department of Business Administration, Lahore Leads University, Pakistan \\ *E-mail address: shafique.nouman@gmail.com, naveeddgk2010@gmail.com
}

\begin{abstract}
Currently the world is experiencing a tremendous growth in the use of social networking sites (SNS). Virtual communities is Increasing day by day, there is still a lack of studies analyze on role of virtual community in impulse buying on the base of trust. Dramatic change in the technology it play role for the virtual communities. Virtual community is a group of people who share common interest and practices, who tend to communicate to each other on the regular base over internet via a common mechanism or location (e.g. social networking websites). Generally, virtual communities serve discussion forums where people communicate with each other and sharing common interest via an electronic media. Virtual communities play role both the retailer and consumer to communicate and discuss information regarding various product of interest.
\end{abstract}

Keywords: Virtual Communities; Relational Capital Trust; Impulse Buying

\section{INTRODUCTION}

Dramatic change in the technology it play role for the virtual communities. Virtual community is a group of people who share common interest and practices, who tend to communicate to each other on the regular base over internet via a common mechanism or location (e.g. social networking websites) (Ridings, Gefen, and Arinze, 2002). Generally, virtual communities serve discussion forums where people communicate with each other and sharing common interest via an electronic media. Virtual communities play role both the retailer and consumer to communicate and discuss information regarding various product of interest (Valck, Bruggen, \& Wierenga, 2009).

Social networking describe as virtual space where "user can join network organized by city, workplace and region to connect and interact with each other. People can also add friends and send message to them and update their profile to notify friends about themselves (Casteleyn, Mottart, and Rutten, 2009).means social websites are also a forum where people can communicate each other, add friends and send their personal profile to tell about them like the faccebook,twitter etc. There is a wide range of social media such as YouTube and Flickr as social sharing sites via social Networks like LinkedIn and Face book (Hensel and Deis, 2010). Online social networking site typically involves a collection of user profiles where registered members can place information that they want to share with others. Due to 
social websites day by day the virtual communities are increase. Mostly students are using the social websites. So that people can share ideas and information with their virtual communities' member.

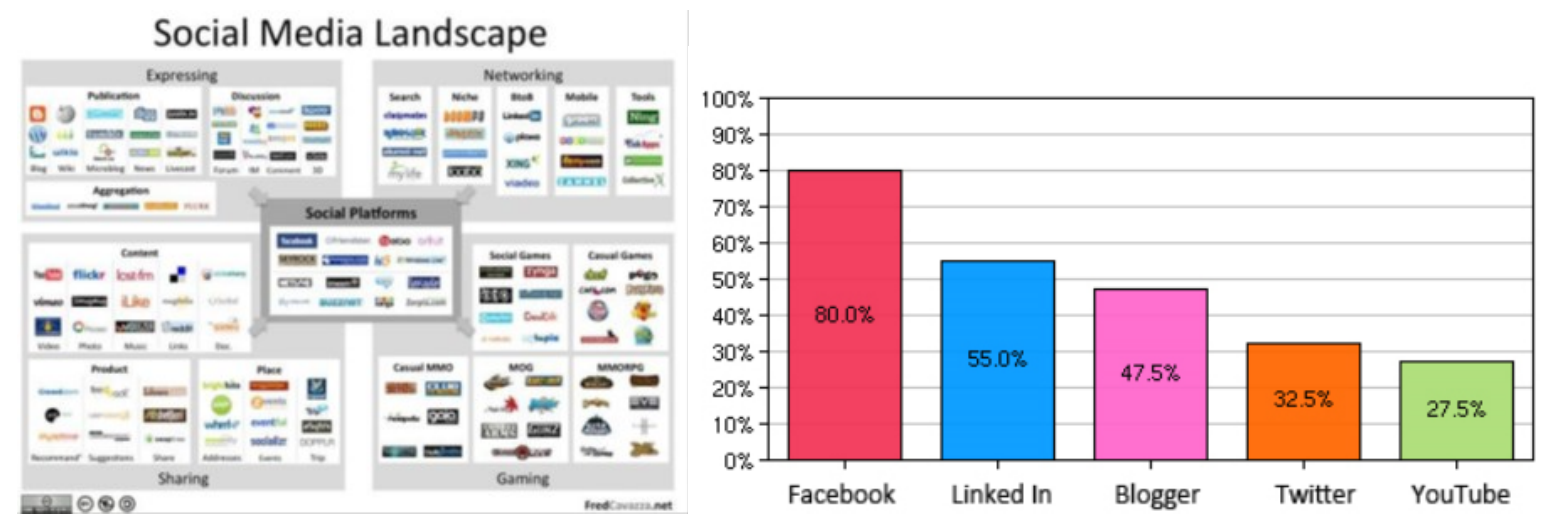

A virtual community (online group) is a group of people who exchange words and ideas of common interests, hobbies or products in an online space. Different types of virtual communities are E-Bulletin boards or message boards, product forums, blogs by individuals, chat rooms, online shopping websites and social networking groups. Some examples of product related virtual communities are eopinions.com, cnet.com, amazon.com, and ebay.com. Store/product fan groups in social networking websites such as facebook.com, myspace.com and twitter.com are also a part of virtual communities.

Increase of the social networking websites like the twitter and face book have attracted attention to shoe interest toward marketing implication associated with social platforms. (Casteleyn et al., 2009; Firat \& Dholakia, 2006). There are many factors which can play role to encourage the participant in online grouping of many social networking websites such as enterainment,information available and self-status seeking. (Park, Kee, \& Valenzuela, 2009; Valck et al, 2009). Conventional networking platforms like blogs, forums, and newsgroups have gone into a new form of networking through social websites (Tikkanen, Hietanen, Henttonen, \& Rokka, 2009).

\section{Problem Statement}

Currently the world is experiencing a tremendous growth in the use of social networking sites (SNS). Virtual communities is Increasing day by day, there is still a lack of studies analyze on role of virtual community in impulse buying on the base of trust.

\section{Research Questions}

How virtual community participants play role in impulse buying?

$>$ How relational capital trusts moderate between virtual community and impulse buying?

\section{Research Objective}

To examine how the virtual community participants affect impulse buying identify the effect of virtual community on impulse buying. 
International Letters of Social and Humanistic Sciences 8(2) (2015) 115-122

To investigate the moderating effect of relational capital trust on the relationship proposed in the first on objective.

$>$ To identify that virtual platforms are good place for discussion about the product.

\section{Purpose of this study}

The purpose of this study is to see that how virtual community influence the impulse buying. Especially on that how the relational capital trust influence as a moderate between virtual community and impulse buying.

\section{Research Significance}

Significant of this study is to investigate impact of virtual community in impulse buying with moderating role of relational capital trust. In addition, this study enhances our understanding of moderating role of relational capital trust. Result of this will be beneficial to the educator, online customer and online community policy makers. Educators can use this study as a base to further investigation and explore. This study provides information to consumer educators and virtual community policy makers in regarding information shared in virtual communities and online marketing activities. It is necessary for the police makers to strict policies posted in the online forums because virtual communities can easy to join and mostly free. This study will be helpful for marketing manager that how word of mouth of product or company should be converted into the web world of mouth.

\section{Different Virtual Communities platforms}

- Groups in facebook.com,

- amazon.com,

- Groups in twitter.com,

- ebay.com

- Groups in myspace.com

- cnet.com

- Products/service blogs

- epinions.com

- Any product/service forum websites

- mouthshut.com

\section{Gap of study}

In the most of articles and researches the study is done on the trust of the websites as a second party trust.so little study is done in the trust of third party like the virtual communities that how the third party play role on the impulse buying behavior of the customer.so identify that area how can we research on the third party like the virtual communities.

\section{Theoretical support}

Theoretical support took for this study by the social identity theory. Social identity theory has given great emphasis on the common understandings that underlie group membership (Postmes (2005). Shared understanding among the social network helps 
community member's social identity to get strengthen, and this happens through the process of self-categorization and emotional involvement (Ellemers (1999)). This shared understanding can help social network members in comprehending the essence of group norms, which can drive towards a higher identification with the network (Dholakia (2004). Social Impact theory was developed by (Bibb Latané, 1981). Latané described social impact as a phenomenon in which people affect one another in social situations. This theory says that people in a specific situation affect by each other so that is called the social impact. In virtual community people are connected to each other which shared their ideas so that their idea impact on the other customer which wants to buy any things.so that I used the social impact theory which is given by the Latane.

\section{LITRAUTURE REVIEW}

\subsection{Virtual Community}

Virtual community concept has been defined from a social point of view. With this perspective, the concept of virtual community is firstly defined by Rheingold (1993) as a social group that is originated in the internet when people discuss in this communication channel. Virtual community is a group of people with a common interest that interact regularly in an organized way over the internet (Riding et al, 2002). A virtual community is a social network of individuals who interact through specific social media potentially crossing geographical and political boundaries in order to pursue mutual interests or goals. One of the most pervasive types of virtual community operates under social networking services consisting of various online communities. Therefore, one of the main advantages of virtual communities is that, due to the internet, these communities can overcome the space and time barriers to interaction that exist in traditional communities (Andersen, 2005). Social groups have existence for their participant and they can influence their member behavior (Muniz and O'Guinn, 2001).virtual communities member have ability to influence the behavior of their other member in the group. Secondly, virtual communities help to identify the need of participant individuals or group of the people (Kozinets, 2002).Group member in the virtual communities play role to identify the need of their social group member.

\subsection{Relational Capital Trust}

Relational social capital can generate a condition in which the information is adopted sooner without the critical evaluation because of high level of trust and reciprocity among the members. Relational capital is the dimension of the social capital and refer the affective nature with in the social group (Wasko and Faraj, 2005).Social capital a "person social characteristics including social skills, charisma and the size of his Rolodex, which enables him to reap market and non-market returns from interactions with others" (Adler, 2002). Three dimensions of social capital: structural social capital, relational social capital, and cognitive social capital has been put forward (Nahapiet and Ghoshal, 1997). Relational Social capital specifies when and why community members share information (Huysman (2006). Relational capital which is the dimension of the social capital say why the member in the social group shared information on what purpose and why. 
International Letters of Social and Humanistic Sciences 8(2) (2015) 115-122

So relational dimension have strong impact on social group members' behavior, such as their commitment to the social group members. Among all the factors used to measure the relational capital, we have chosen the concept of trust since it has often been associated with the achievement of long lasting and profitable relationships (Anderson and Narus, 1990). Trust has been analyzed from two different perspectives (Geyskens et al., 1996; Kumar et al., 1995; Moorman et al., 1993). On the one hand, trust has been considered as a behavioral component, which is associated with the willingness or desire to rely on the partner (Geyskens et al., 1996; Kumar et al., 1995; Moorman et al., 1993).

On the other hand, trust may be analyzed as a cognitive component, which reflects the result of the assessment that one party makes of the credibility and goodwill of the other party (Anderson and Narus, 1990; Doney and Cannon, 1997; Ganesan, 1994; Mayer et al., 1995). Considering trust as a cognitive component, it has been usually suggested that trust may be defined by three types of beliefs which can be differentiated on the levels of competence, honesty and benevolence, as perceived by the individual. In general, competence is related to the individual's perceptions of the other party's knowledge and skills to complete a relationship and satisfy the needs of the individual (Coulter and Coulter, 2002). In the context of virtual communities, which are always centered on a specific mutual concern, competence refers to the skills of the community members with respect to that mutual interest (Ridings et al., 2002). In turn, honesty is the belief that the second party will keep their word, fulfil their promises and be sincere (Doney and Cannon, 1997; Gundlach and Murphy, 1993).

Finally, benevolence reflects the belief that one of the parties is interested in the wellbeing of the other. Indeed, a benevolent attitude is expected to condition the behaviour of the other party in the event that unforeseen circumstances arise (Ganesan, 1994). In the context of virtual communities, benevolence refers to the expectation that community members will have the intention and the desire to help, support and care for the other members of the virtual community (Ridings et al., 2002). Thus, honesty and benevolence help to guarantee that other community members will not carry out opportunistic behaviors in the virtual community.

Purchasing decisions are often strongly influenced by people who the consumer knows and trusts in both online and offline context (Young 2007).It means when the trust level is high in the member of the virtual communities so the that people in the group strongly influence on each other. Social networks allow the consumer to share the experience with their trusting member and influence their urge to buy. Consumers are more likely to believe recommendations from people they know and trust like friends and family members (Sinha and Swearingen, 2001).On the social websites people mostly trust and believe the member that they kow. Compliance process can be influenced by the relational social capital when the members in the network are more attached based on the trust and reciprocity which considered as the relational assets (Tsai, 1998 and Daniel 2003).

\subsection{Impulse Buying}

When the purchase motivation is emotional then it is called the impulse buying (ShuLing, Yung-Cheng, \& Chia-Hsien, 2009, p. 275). When the customer are emotional involve so that impulse buying purchase will be occur.Impulse buying can be defined as an immediate purchase with no pre-shopping intentions (Beatty and Ferrell, 1998).Over-stimulation (i.e. higher than desired excitement) leads to a momentary loss of self-control, thus enhancing the likelihood of impulse purchases. Impulse buying as an unplanned behavior involving quick decision-making and tendency for immediate acquisition of the product (Rook and Gardner, 
1993).impulse buying is a decision making process in which customer immediate take action about any product

\subsection{Conceptual Model for Future Studies}

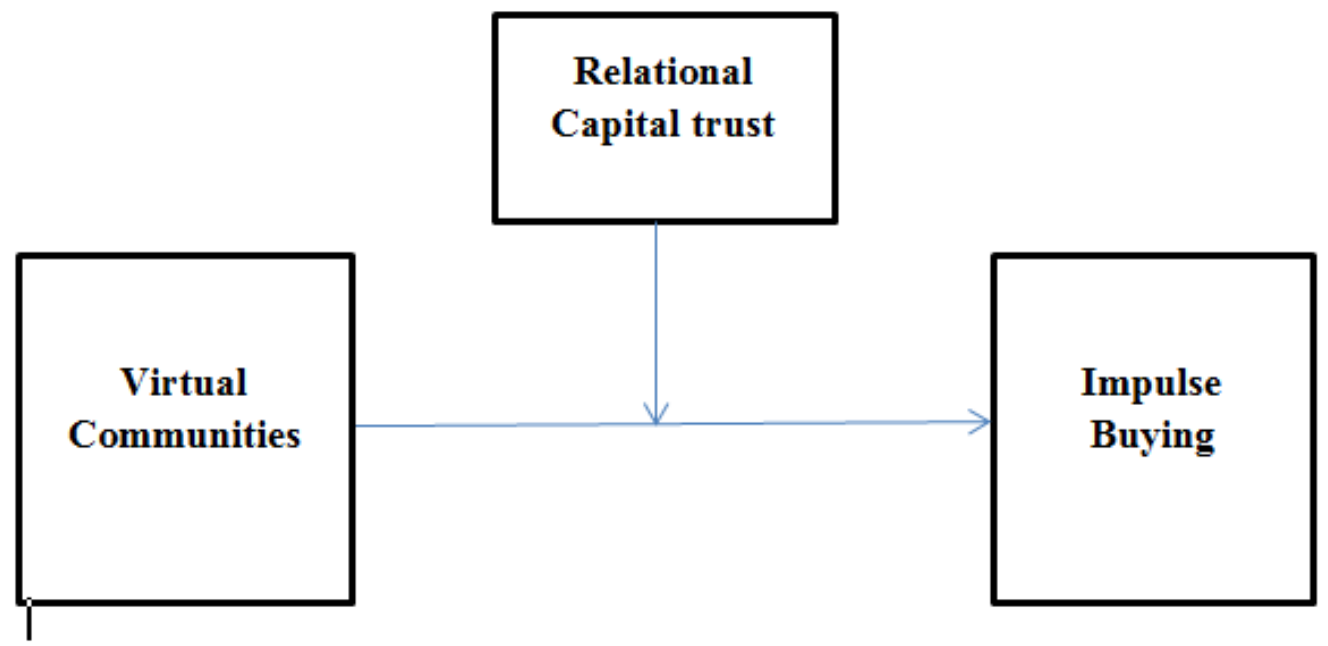

\section{Variables}

Dependent Variable; Virtual community

Moderating Variable; Relational Capital Trust (Honesty; Benevolence; Competence)

Dependent Variable; Impulse Buying

Hypothesis for Future Studies

To meet the objectives, this exploratory research examined the following hypotheses:

H1: There is a relationship between virtual community and impulse buying.

H2: There is a relationship relational capital and impulse buying.

H3: There is a moderating role of relational capital trust relationship between virtual community and relational capital trust

\section{CONCLUSION AND DISCUSSION}

Engaged consumer enhance the connection, empowerment, trust, commitment and emotional bonding. It seems difficult to understand why people actively participate in virtual communities and help other members. Trust is especially important in the context of virtual communities due to the fact that it can help to rule out opportunistic behaviors that can be carried out by some members of the community. A relationship in which both parties trust each other generates enough value so that the parties will be committed to the relationship. Trust is the factor which can influence the consumer between online and offline purchase.

Trusts play very important role on the purchase decision of offline and online. Consumer opinions about customer care in socially-based web sites impact consumer opinions and consumer engagement and consequently consumer choice of brand or company when making purchases. Opinion of the consumer on the web sites impact the consumer choice of brand when they making purchase. Information shared by community member has 
International Letters of Social and Humanistic Sciences 8(2) (2015) 115-122

strong influence on purchase behavior. The influence of $\mathrm{C} 2 \mathrm{C}$ communications in online brand communities on customer purchase behavior.

\section{References}

[1] Lokken, S. L., Cross, G., Halbert, L. K., Lindsey, G., Derby, C., \& Stanford, C. (2003). Comparing online and non-online shoppers. International Journal of Consumer Studies, $27(2), 126-133$

[2] Koufaris, M., Kambil, A., \& Labarbera, P. (2001). Consumer behavior in web-based commerce: An Empirical Study. International Journal of Electronic Commerce, 6(2), $115-138$

[3] Lee, J. Y., \& Park, J. K. (2008). The mediating role of consumer conformity in ecompulsive buying, Advances in Consumer Research, 35, 387-392.

[4] Butler, B. S. (2001). Membership size, communication activity, and sustainability: A resource-based model of online social structures. Information Systems Research, 12(4), 346-362

[5] Datamonitor, (2010). Online Retail Industry Profile: United States

[6] Ridings, C., Gefen, D., \& Arinze, B. (2006). Psychological barriers: Lurker and poster motivation and behavior in online communities. Communications of AIS, 18, 329- 354.

[7] Ridings, C. M., Gefen, D., \& Arinze, B. (2002). Some antecedents and effects of trust in virtual communities. Journal of Strategic Information Systems, 11(3/4), 271-295

[8] Casteleyn, J., Mottart, A., \& Rutten, K. (2009). How to use facebook in your market research. International Journal of Market Research, 51(4), 439-447.

[9] Park, N., Kee, K. F., \& Valenzuela, S. (2009). Being immersed in social networking environment: Facebook groups, uses and gratifications, and social outcomes. CyberPsychology \& Behavior, 12(6), 729-733.

[10] Casteleyn, J., Mottart, A., \& Rutten, K. (2009). How to use facebook in your market research. International Journal of Market Research, 51(4), 439-447.

[11] Firat, A., \& Dholakia, N. (2006). Theoretical and philosophical implications of postmodern debates: Some challenges to modern marketing. Marketing Theory, 6(2), 123-162.

[12] Tikkanen, H., Hietanen, J., Henttonen, T., \& Rokka, J. (2009). Exploring virtual worlds: Success factors in virtual world marketing. Management Decision, 47(8), 1357- 1381.

[13] Moorman, C., Despande', R. and Zaltman, G. (1993), “Factors affecting trust in market research relationships"', Journal of Marketing, Vol. 57 No. 1, pp. 81-101.

[14] Coulter, K. and Coulter, R. (2002), “Determinants of trust in a service provider: the moderating role of length of relationship', Journal of Services Marketing, Vol. 16 No. 1, pp. 35-50.

[15] Doney, P. and Cannon, J. (1997), "An examination of the nature of trust in the buyerseller relationship', Journal of Marketing, Vol. 61 No. 2, pp. 35-51. 
[16] Ridings, C.M., Gefen, D. and Arinze, B. (2002), 'some antecedents and effects of trust in virtual communities', Journal of Strategic Information Systems, Vol. 11, pp. 271-95.

[17] Verplanken, B. \& Herabadi, A. (2001).” Individual Differences in Impulse Buying Tendency: Feeling and No Thinking”. European Journal of Personality, 15, S71-S83

[18] Kumar, N., Scheer, L. and Steenkamp, J. (1995), "the effects of supplier fairness on vulnerable resellers', Journal of Marketing Research, Vol. 32 No. 1, pp. 42-53

[19] Roderick, J. B. Ana, Ilic. Biljana, J. Linda, H. (2011), “Consumer engagement in a virtual brand community: An exploratory analy", Journal of Business Research, 07320; pp. 10

[20] Mavis, T. And Stephanie, M. (2010), “The influence of C2C communications in online brand communities on customer purchase behavior" ,J. of the Acad. Mark. Sci. 38:634653

[21] Quinton, S. and Harridge, S. (2008), “ Trust and online wine purchasing: insights into UK consumer behavior", International Journal of Wine Business Research Vol. 20 No. 1, pp. $68-85$

[22] Karakaya, F. and Ganim, N. 2010, "Impact of online reviews of customer care experience on brand or company selection”, Journal of Consumer Marketing 27/5 pp. $447-457$

[23] Xiao, S.k and Benbasat, I.2004, "Understanding Customer Trust in Agent-Mediated Electronic Commerce,Web-Mediated Electronic Commerce, and Traditional Commerce", Information Technology and Management 5, 181-207, 2004

[24] Kelman, H. (1958), "Compliance, identification, and internalization: Three processes of attitude change", Journal of Conflict Resolution, 2, 51-60.

[25] Gopinathan, N. (2012), "Social influence through social network sites and its influence on online Impulse buying" 